599.735 .5
BUFFALO/VET ERINARY MEDICNE

JNSF23-1-9

J. Natn. Sci. Coun. Sri Lanka 1995 28(1): 9-15

\title{
PREFERENTLAL PHAGOCYTOSIS OF BACTERIA IN MIXED CULTURES BY BUFFALO (BUBALUS BUBALIS) NEUTROPHIIS
}

\section{INDIRA D. SILVA ${ }^{* 1}$ and R.O. THATTIL ${ }^{2}$}

1 Department of Clinical Studies, Faculty of Veterinary Medicine \& Animal Science, University of Peradeniya, Peradeniya.

2 Department of Crop Science, Faculty of Agriculture, University of Peradeniya, Peradeniya.

\section{(Received : 17 March 1994; accepted: 03 February 1995)}

\begin{abstract}
Comparative phagocytic activity of buffalo blood neutrophils incubated simultaneously with pure and mixed cultures of Escherichia coli, Staphylococcus aureus, and Streptococcus agalactiae was studied. Phagocytic activity for pure bacterial cultures of Staph. aureus, Strep. agalactiae and E. coli were $90.8 \%, 85.4 \%$ and $76.2 \%$, respectively. The percent phagocytosis of neutrophils incubated with mixed bacterial cultures was similar to that with pure bacterial cultures. However, with mixed bacterial cultures, a majority of neutrophils showed preferential phagocytosis of one species of bacteria. Thus, neutrophils incubated with a mixed bacterial culture of $E$. coli and Staph. aureus showed a significantly higher phagocytosis of Staph. aureus, with a per cent phagocytosis of approximately $40 \%$. Neutrophils incubated with a mixed bacterial culture of $E$. coli and Strep. agalactiae showed a significantly higher phagocytosis of Strep. agalactiae, with a percent phagocytosis of approximately 33\%. These observations indicate that when buffalo neutrophils are exposed to a mixed bacterial culture the affinity for phagocytizing $E$. coli was much less in the presence of Staph. aureus than in the presence of Strep. agalactiae.
\end{abstract}

Key words: Buffalo, mixed bacterial cultures, neutrophil, phagocytosis.

\section{INTRODUCTION}

Mastitis is a major cause of economic loss in the dairy industry. Although the buffalo is becoming popular as a dairy animal in Asia, little information is available, in general, on mastitis in buffaloes. Since the buffalo udder is relatively pendulous with long teats, it is more liable to injury and infection than the udder of a cow. ${ }^{1}$ Bacteria are the major cause of udder infections. Bacteriological studies on clinical mastitis in buffaloes have demonstrated that the most prevalent species isolated from mastitic quarters were staphylococci (Staphylococcus aureus \& Staphylococcus epidermidis) and streptococci (Streptococcus agalactiae \& Streptococcus dysgalactiae), while $E$. coli was the main gram-negative bacterium isolated..$^{2-6}$ Other than the defense mechanisms in the teat, phagocytic cells are the most important defense mechanism against ascending infections of the mammary gland. ${ }^{7}$

A simultaneous comparative evaluation of the phagocytic activity of buffalo blood neutrophils had revealed that the phagocytosis was highest for Staph. aureus, followed by similar phagocytic activity for Strep. agalactiae and E. coli. ${ }^{8}$ Furthermore, neutrophils isolated from buffalo milk were as efficient as blood neutrophils in their phagocytic activity when allowed to interact with these three bacteria opsonized with serum. ${ }^{9}$

\footnotetext{
- Corresponding author.
} 
However, this property of the neutrophils was studied using the microorganisms in pure cultures. Common mammary pathogens namely, Staph. aureus, Strep. agalactiae and E. coli may cause mastitis in pure or mixed infections. ${ }^{2,10}$ Previous workers have observed that $11 \%$ of the mastitic buffalo quarters tested had mixed infections. ${ }^{2}$ In mastitis due to mixed infections, neutrophils may be required to phagocytose and kill more than one species of microorganisms. Previous studies have indicated that the phagocytic activity of cattle neutrophils for bacteria in mixed cultures was not identical to those in pure cultures. ${ }^{11}$ Therefore, it is of clinical significance to compare and evaluate phagocytic activities of buffalo neutrophils for different micro-organisms in mixed cultures. We report here on a study of the phagocytic activity of buffalo blood neutrophils exposed to pure and mixed cultures of E. coli, Staph. aureus and Strep. agalactiae.

\section{METHODS AND MATERIALS}

About $25 \mathrm{ml}$ of blood was collected into EDTA vacutainers from each of 12 Lankan buffaloes (Bubalus bubalis) by jugular venepuncture according to the ethical guidelines. Blood was collected also into two $10 \mathrm{ml}$ vacutainers without the anticoagulant to obtain fresh serum. The age of buffaloes used varied from 3 to 10y. Total and differential leukocyte counts were within the normal range for the buffalo. ${ }^{12}$

Isolation of neutrophils from buffalo blood: The neutrophils were isolated and the viability was tested as described earlier. ${ }^{13}$ The viability of the isolated cell suspension varied from 94 to $100 \%$ and consisted of 80 to. $90 \%$ neutrophils. A working suspension of $5 \times 10^{3}$ viable neutrophils/ $\mu$ in sterile $0.8 \% \mathrm{NaCl}$ in $0.0132 \mathrm{M}$ phosphate buffer, $\mathrm{pH} 7.2$ (PBS) with $2 \%$ bovine serum albumin was prepared and kept at $4^{\circ} \mathrm{C}$ until use.

Preparation of bacterial cultures: E. coli (ATCC 25922), Staph. aureus (ATCC 29213) and Strep. agalactiae were isolated from bovine mastitic milk. Separate suspensions of the three bacteria were prepared to obtain a concentration of $1 \times 10^{6}$ organisms $/ \mu$ in $\mathrm{PBS}^{13}$ and the three bacteria were opsonized separately ${ }^{8}$ using serum of the particular buffalo for each assay. A neutrophil : bacteria ratio of approximately 1:50 was used for optimum phagocytosis.

Four hundred $\mu$ l of opsonized E. coli, Staph. aureus \& Strep. agalactiae were aliquoted separately into three glass tubes. These three tubes constituted the pure bacterial cultures. Then $200 \mu \mathrm{l}$ each of opsonized E. coli \& Staph. aureus, and $200 \mu \mathrm{l}$ each of opsonized E. coli \& Strep. agalactiae were aliquoted separately into two glass tubes. These two tubes constituted the mixed bacterial cultures.

Phagocytosis assay: In a single experimental run, the five suspensions of microorganisms were incubated with $400 \mu$ of the neutrophil suspension prepared from one buffalo. In the negative control the bacterial aliquot was substituted with PBS. The phagocytosis assay was carried out as described earlier. ${ }^{8}$ 
Staining and microscopic evaluation: Smears stained with $2 \%$ methyl green and counter stained with Leishman stain $^{8}$ were examined microscopically under an oil immersion objective $(x 1,250)$. The nuclei of leukocytes stained light green and the bacteria acquired different degrees of blue. The per cent phagocytosis (PP) or the percentage of phagocytically active neutrophils (cells with ingested bacteria) was determined by counting 500 neutrophils. Neutrophils incubated with mixed bacterial cultures were categorized into cells that had ingested only rods $(E$. coli), cells that had ingested only cocci (Staph. aureus or Strep. agalactiae), and cells that had ingested both rods and cocci (E. coli and Staph. aureus or E. coli and Strep. agalactiae). The neutrophils in the negative control tube (without bacteria) did not show ingested particles.

Statistical analyses: The means and standard errors (S.E.) of the means were calculated for the PP of neutrophils in pure cultures. To analyze the phagocytic activity in mixed cultures of $E$. coli + Staph. aureus and $E$. coli + Strep. agalactiae, the neutrophils were divided into three groups, namely, neutrophils which phagocytized E. coli only, neutrophils which phagocytized Staph. aureus / Strep. agalactiae only, and neutrophils which phagocytized both E. coli and Staph. aureus or $E$. coli and Strep. agalactiae. These three groups were subjected to the analysis of variance and the least significant difference was used in the comparison of means.

\section{RESULTS}

Percentages of neutrophils showing phagocytosis or PP following incubation with either pure or mixed cultures of $E$. coli with Staph. aureus or Strep. agalactiae are shown in Tables 1 and 2. Neutrophils incubated with mixed bacterial cultures did not always phagocytize both species of bacteria. The tables give the means and the S.E. of the means of the PP in pure cultures. The mean PP of the three groups of neutrophils, namely, neutrophils which phagocytized $E$. coli only, neutrophils which phagocytized Staph. aureus/Strep. agalactiae only, and neutrophils which phagocytized both $E$. coli and Staph. aureus or $E$. coli and Strep. agalactiae and the least significant differences used to compare the means are also given in Tables 1 and 2.

\section{Phagocytosis of pure and mixed cultures of $E$, coli and Staph. aureus}

The PP of E. coli in pure culture was $76.2 \%$, and that of Staph. aureus in pure culture was $90.8 \%$, and the total PP of E. coli and Staph. aureus in mixed culture was $87 \%$ (Table 1). In the mixed culture, the PP of Staph. aureus only (38.6\%) was significantly higher $(\mathrm{p}<0.01)$ than that for $E$. coli only $(8 \%)$ but was similar to the PP of both bacteria $(40.5 \%)$. 
Table 1: Percent phagocytosis of buffalo neutrophils for E. coli and Staph. aureus in pure and mixed cultures.

Organism Percent phagocytosis Mean S.E. of mean

Pure cultures

E. coli

Staph. aureus

Mixed culture

E. coli only

Staph. aureus only

$38.6^{\mathrm{a}}$

Both bacteria

$40.5^{\mathrm{a}}$

Total

In mixed bacterial culture, the total represents combined percent phagocytosis for E. coli only, Staph. aureus only, and both bacteria. The least significant difference was 21.3. , $^{\mathrm{b}}$ Means with the same letters were not significantly different.

\section{Phagocytosis of pure and mixed cultures of E. coli and Strep. agalactiae}

The PP of $E$. coli in pure culture was $76.2 \%$ and that of Strep. agalactiae in pure culture was $85.4 \%$, and the total PP of $E$. coli and Strep. agalactiae in mixed culture was $82.4 \%$ (Table 2). In the mixed culture, the PP of Strep. agalactiae only $(31.5 \%)$ was significantly higher $(\mathrm{p}<0.01)$ than that for $E$. coli only $(10.8 \%)$ but was lower than the PP of both bacteria (40.1\%). In the mixed cultures tested, the percentage of cells showing phagocytosis of both bacteria were similar, with a PP of $40.5 \%$ for $E$. coli + Staph. aureus, and $40.1 \%$ for $E$. coli + Strep. agalactiae.

Table 2: Percent phagocytosis of buffalo neutrophils for $E$. coli and Strep. agalactiae in pure and mixed cultures.

Organism

Pure cultures

E. coli

Strep. agalactiae

76.2

85.4

2.0

Mixed culture

E. coli only

$10.8^{\mathrm{b}}$

Strep. agalactiae only

Both bacteria

Total

In the mixed bacterial culture, the total represents combined percent phagocytosis for $E$. coli only, Strep. agalactiae only, and both bacteria. The least significant difference was 17.5. a,b Means with the same letters were not significantly different. 


\section{DISCUSSION}

Cell-mediated immunity (CMI), humoral immunity and non-specific resistance constitute the defense mechanisms of the mammary gland. ${ }^{14}$. The role of the CMI in the pathogenesis of mastitis is not well understood. However, lymphokines secreted by the primed lymphocytes located in the mucous membrane of the gland enhance the attraction of leukocytes resulting in mobilization of phagocytic cells from the blood vessels in the region, thus providing resistance against most mammary pathogens. ${ }^{14-16}$ The well known California mastitis test (CMT) indirectly measures the concentration of these cells in mastitic milk. The specific activity of phagocytes and their bactericidal action can be enhanced by the presence of opsonins and cytophilic antibody which comprize the humoral immunity. ${ }^{17}$ Other than the defense mechanisms in the teat, phagocytic cells are the most important defense mechanism against ascending infections of the mammary gland. ${ }^{7}$ However, the teat sphincter in the buffalo contains more smooth muscle fibres and blood vessels, and might therefore function as a better barrier against infection than the cow udder. ${ }^{18}$

A simultaneous comparative evaluation of the phagocytic activity of buffalo neutrophils revealed that the phagocytic activity was highest for Staph. aureus, followed by similar phagocytic activity for Strep. agalactiae and E. coli. ${ }^{8}$ When compared with cattle neutrophils, the percent phagocytosis of buffalo neutrophils was $22.5 \%$ higher for Staph. aureus, $8 \%$ lower for E. coli, and similar to that of cattle neutrophils for Strep. agalactiae. ${ }^{8}$ This may explain the finding that buffaloes are more resistant to mastitis caused by Staph. aureus than cattle. ${ }^{19}$

Similar studies on cattle neutrophils and mixed bacterial cultures, demonstrated a low preference for phagocytizing $E$. coli in the presence of Strep. agalactiae, but not in the presence of Staph. aureus. ${ }^{11}$ The present study demonstrates that the buffalo neutrophils also show a poor preference for phagocytizing $E$ : coli, but the affinity of buffalo neutrophils for internalizing $E$. coli was much less in the presence of Staph. aureus than in the presence of Strep. agalactiae. Thus, it was interesting to note that the buffalo neutrophils preferentially phagocytosed Staph. aureus, whereas, the cattle neutrophils preferentially phagocytosed Strep. agalactiae over E. coli.

Several studies have reported on the inhibition of phagocytic activity of phagocytes by micro-organisms or their metabolic products. ${ }^{20-23}$ Factors concerned with preferential phagocytosis of an organism in a mixed culture need elucidation. Preferential phagocytosis may be partly due to a stimulation or inhibition imposed by one particular species of organism against the other, possibly through induction of changes in appropriate membrane receptors. This influence on phagocytic activity did not seem to affect the total neutrophil population, since a proportion of neutrophils phagocytized both species of bacteria. It is possible that the age of the neutrophils may also play a role in the potential of their phagocytic activity. The number of bacteria available for phagocytosis was not a factor because the neutrophil:bacteria ratio was 1:50 in all experiments achieving optimum phagocytosis. 
The findings of the present -study warrant studies on the resistance of buffaloes against clinical mastitis due to a mixed infection including Staph. aureus and the appropriate treatment regime for mastitis due to mixed bacterial infections.

\section{Acknowledgement}

This study was supported in part by the Swedish Agency for Research Cooperation and the Natural Resources, Energy, and Science Authority of Sri Lanka, (BF-30). The authors thank Mr. K.A.M.J. Silva and Mr. K.R.J.K. Amararatne for technical assistance.

\section{References}

1. Mohan R.N. (1968). Diseases and parasites of buffaloes. 2. Bacterial and fungal diseases. Veterinary Bulletin 38: 647-659.

2. Kapur M.P., Sharma A. \& Bhardwaj R.M. (1988). Bacteriology of clinical mastitis in buffaloes. Proceedings of the Second World Buffalo Congress IV: 44-47.

3. Paranjape V.1. \& Das A.M. (1986). Mastitis among buffalo population of Bombay, a bacteriological report. Indian Veterinary Journal 63: 438-441.

4. Chaudary Z.I., Khan J.M. \& Basra M.A. (1982). Studies on the Staphylococcus mastitis in buffaloes. Pakistan Journal of Scientific Research 34: 79-84.

5. Char N.L., Rao P. \& Rao P.V.R. (1983). Studies on mastitis in buffaloes. Livestock Advisor 8: 19-22.

6. Kalra D.S. \& Dhanda M.R. (1964). Incidence of mastitis in cows and buffaloes in North-West India. Veterinary Record 76: 219-222.

7. Paape M.J., Pearson R.E., Wergin W.P. \& Guidry A.J. (1979). LeukocytesSecond line of defense against invading mastitis pathogens. Journal of Dairy Science 62: 135-153.

8. Silva I.D. (1993). Phagocytic efficiency of buffalo (Bubalus bubalis) blood neutrophils for common mammary pathogens. Buffalo Journal 2: 181-185.

9. Silva I.D. (1993). A comparison of the phagocytic efficiency of buffalo (Bubalus bubalis) blood and milk neutrophils. Sri Lanka Veterinary Journal 40: (in press).

10. Brolund L. (1985). Cell counts in bovine milk, causes of variation and applicability for diagnosis of subclinical mastitis. Acta Veterinaria Scandinavica Suppl. 80: 1-5. 
11. Silva I.D., Jain N.C., Farver T.B. \& Zinkl J.G. (1988). Phagocytic and postphagocytic activities of bovine neutrophils for pure and mixed bacterial cultures. Journal of Dairy Science 71: 2513-2519.

12. Shukla P.C., Pande M.B., Desai H.B. \& Desai M.C. (1981). Haematological and chemical status of blood of local cattle and buffaloes of Panchmahals district of Gujarat State. Indian Journal of Animal Research 15 (2): 103-106.

13. Silva I.D. \& Jain N.C. (1988). Phagocytic and nitroblue tetrazolium reductive properties of bovine neutrophils for mammary pathogens. Journal of Dairy Science 71: 1625-1631.

14. Sears M. (1984). Immunization and immunity. In. Symposium on Bovine Mastitis. Veterinary Clinics of North America: Large Animal Practice 6(2): 391-398.

15. Jain N.C. (1976). Neutrophil leukocyte and inflammation of the bovine mammary gland. Theriogenology 6:153-173.

16. Paape M.J., Pearson R.E., Wergin W.P. \& Guidry A.J. (1977). Enhancement of chemotactic response to polymorphonuclear leucocytes into mammary gland and isolation from milk. Journal of Dairy Science 60: 53-62.

17. Targowski S.P. \& Berman D.T. (1975). Leukocyte response of bovine mammary gland to injection of killed cells and cell walls of Staphylococcus aureus. American Journal of Veterinary Research 36: 1561-1565.

18. Krishnaswamy S., Vedanayaham A.R. \& Varma K. (1965). Studies on mastitis in cattle. Indian Veterinary Journal 42: 92-103.

19. Wanasinghe D.D. (1985). Mastitis among buffaloes in Sri Lanka. Proceedings of the First World Buffalo Congress IV:1331-1333.

20. Nonoyama S., Kojo S., Mine Y., Nishida M., Goto S. \& Kuwahara S. (1979). Inhibitory effect of Pseudomonas aeruginosa on the phagocytic and killing activity of rabbit polymorphonuclear leukocytes: mechanisms of action of a polymorphonuclear leukocyte inhibitor. Infection and Immunity 24:399-403.

21. Ryu H., Kaeberle M.L., Roth J.A. \& Griffith R.W. (1984). Effect of Type A Pasteurella multocida fractions on bovine polymorphonuclear leukocyte functions. Infection and Immunity 43: 66-71.

22. Walker R.D., Schultz T.W., Hopkins F.M. \& Bryant M.J. (1984). Growth phase-dependent phagocytosis of Pasteurella haemolytica by bovine pulmonary macrophages. American Journal of Veterinary Research 45:1230-1234.

23. Gemmell C.G., Peterson P.K., Schmeling D.J. \& Quie P.G. (1982). Effect of staphylococcal alpha toxin on phagocytosis of staphylococci by human polymorphonuclear leukocytes. Infection and Immunity 38: 975-980. 